\title{
COMMENTARY
}

\section{Drotrecogin alpha: a rational approach to the treatment of submassive pulmonary embolism?}

\author{
Charles Marc Samama* and Anne Godier \\ See related research by Dempfle et al., http://ccforum.com/content/15/1/R23
}

\begin{abstract}
Combining therapeutic doses of low-molecularweight heparins and increasing doses of recombinant activated protein $C$ - Drotrecogin alpha (activated), or DAA - is of theoretical interest with regard to the control of coagulation activation. The study by Dempfle and colleagues presents new data showing that endogenous activated protein C levels do not increase in nonseptic patients with pulmonary embolism. However, the results of the addition of these two treatments are puzzling, leaving unresolved the questionable clinical relevance of this combination and the possible increase in bleeding risk.
\end{abstract}

In this issue of Critical Care, Dempfle and colleagues [1] present an original double-blind study assessing the biological effect of the combination of enoxaparin and Drotrecogin alpha (activated) (DAA) (recombinant human activated protein $C$ ) for the treatment of acute submassive pulmonary embolism (PE). The authors demonstrate that DAA infusion accelerates the control of coagulation activation in patients with a $\mathrm{D}$-dimer level higher than $4 \mathrm{mg} / \mathrm{L}$.

This phase II exploratory study sponsored by Eli Lilly and Company (Indianapolis, IN, USA) [2] is of special interest because the use of thrombolytic therapy in patients with submassive PE is a matter of significant and ongoing debate $[3,4]$. Low-molecular-weight heparins (LMWHs) still represent the gold standard for the treatment of venous thromboembolism, as they have proven to be very effective and to have a high efficacy/ safety ratio [5]. Nevertheless, evidence suggests that

*Correspondence: marc.samama@htd.aphp.fr

Department of Anaesthesiology and Intensive Care Medicine, Hotel-Dieu University Hospital, 1, place du Parvis de Notre-Dame, 75181 Paris Cedex 04, France thrombolytic agents may rapidly dissolve blood clots and might reduce the death rate associated with PE. However, there are concerns about the possible risk of adverse effects of these agents, such as life-threatening hemorrhage. Therefore, another antithrombotic drug could be an attractive alternative.

DAA, a vitamin K-dependent protein, is a potent anticoagulant agent that inhibits activated coagulation factors V and VIII (Va and VIIIa) [6]. This mechanism is responsible for a significant reduction in thrombin generation. It also promotes fibrinolysis by inhibiting fibrinolytic inhibitors such as plasminogen activator inhibitor-1 and thrombin-activatable fibrinolysis inhibitor. The global resultant effect of DAA on coagulation is more than complex. Dhainaut and colleagues [7] have demonstrated that this compound could be beneficial in overt and nonovert disseminated intravascular coagulation patients while partially controlling the activation of the system. Moreover, DAA has been used in managing acute myocardial infarction patients after thrombolysis [8]. As an activation of the coagulation system with a high level of thrombin generation is often observed in (nonseptic) PE patients, combining DAA with an LMWH could be understood as a very interesting hypothesis in this regard, even if the sum of the two parts is not as great as the whole.

Dempfle and colleagues have compared increasing doses of DAA for a short duration of infusion (12 hours) with placebo in enoxaparin-treated patients. Up to now, little has been known about the endogenous plasma level of activated protein $\mathrm{C}$ in (nonseptic) PE patients. Interestingly, the endogenous activated protein $\mathrm{C}$ levels were elevated in the DAA-treated group but not in the control group. This unexpected finding represents the pivotal data of this study, creating the potential for further developments in the field.

Unfortunately, the road to improve our understanding of drugs is not always straightforward. Some hurdles can slow down the development of our projects. Sometimes, physicians use shortcuts to save time, forgetting that pharmacology follows very strict rules. It seems that no 
animal study and no phase 1 study were performed before the start of the study by Dempfle and colleagues. Combining a potent anticoagulant (LMWH) with another one (DAA) should have been tested, at least, in healthy volunteers.

Furthermore, if LMWHs have already been given concomitantly with therapeutic doses of DAA in the past [9-11], the doses were only prophylactic, and, to our knowledge, no therapeutic doses have ever been combined with DAA in nonseptic patients, and this is because the bleeding risk of these patients is much different than that of hypercoagulable septic patients. As already mentioned, DAA develops an anticoagulant activity. In several pivotal DAA trials in sepsis, some major bleeding episodes have been reported to be related to this anticoagulant effect $[10,11]$. Moreover, in daily clinical practice, the induced-bleeding risk of DAA was reported to be much higher than that of the control trials [12]. In the study by Dumpfle and colleagues, which is actually registered as a safety study [2], the observed results are a little bit disappointing, leaving unresolved the potentially increased bleeding risk. The authors state that DAA accelerates the control of coagulation activation in a subgroup of patients with high levels of intravascular fibrin. Is there any clinical need for that? No significant difference is observed in echocardiographic data between the treated group and the control group. Finally, as one patient in the DAA group developed an intracranial hemorrhage (which is fairly uncommon in enoxaparintreated patients), the question of the clinical benefit of such a combination has to be raised, notwithstanding the low power of this study to detect an increase in major bleeding. Eventually, the debate remains very interesting. DAA is a fascinating compound, and its never-ending story is complex!

\section{Abbreviations}

DAA, Drotrecogin alpha (activated); LMWH, low-molecular-weight heparin; PE, pulmonary embolism.

Competing interests

The authors declare that they have no competing interests.

Published: 22 February 2011
References

1. Dempfle C, Elmas E, Link A, Suvajac N, Liebe V, Janes J, Borggrefe M: Endogenous plasma APC levels and effect of enoxaparin and drotrecogin alfa (activated) on markers of coagulation activation and fibrinolysis in pulmonary embolism. Crit Care 2011, 15:R23.

2. ClinicalTrial.gov: Adjuvant treatment of pulmonary embolism with Drotrecogin alfa (activated): phase II exploratory study [http://clinicaltrials. gov/ct2/show/NCT00191724]

3. Dong BR, Hao Q, Yue J, Wu T, Liu GJ: Thrombolytic therapy for pulmonary embolism. Cochrane Database Syst Rev 2009, (3):CD004437.

4. Ramakrishnan N: Thrombolysis is not warranted in submassive pulmonary embolism: a systematic review and meta-analysis. Crit Care Resusc 2007, 9:357-363.

5. Kearon C, Kahn SR, Agnelli G, Goldhaber S, Raskob GE, Comerota AJ; American College of Chest Physicians: Antithrombotic therapy for venous thromboembolic disease: American College of Chest Physicians EvidenceBased Clinical Practice Guidelines (8th Edition). Chest 2008, 133 (6 Suppl):454S-545S.

6. Borgel D, Bornstain C, Reitsma P, Lerolle N: A comparative study of the protein C pathway in septic and nonseptic patients with organ failure. Am $J$ Resp Crit Care Med 2007, 176:878-885.

7. Dhainaut J-F, Yan SB, Joyce DE, Pettilä V, Basson B, Brandt JT, Sundin DP, Levi $M$ : Treatment effects of drotrecogin alfa (activated) in patients with severe sepsis with or without overt disseminated intravascular coagulation. J Thromb Haemost 2004, 2:1924-1933.

8. Sakamoto T, Ogawa H, Takazoe K, Yoshimura M, Shimomura H, Moriyama Y, Arai $\mathrm{H}$, Okajima K: Effect of activated protein $\mathrm{C}$ on plasma plasminogen activator inhibitor activity in patients with acute myocardial infarction treated with alteplase: comparison with unfractionated heparin. J Am Coll Cardiol 2003, 42:1389-1394.

9. Bernard G, Vincent J, Laterre P, LaRosa S: Efficacy and Safety of Recombinant Human Activated Protein C for Severe Sepsis. N Engl J Med 2001, 344:699-709.

10. Abraham E, Laterre PF, Garg R, Levy H, Talwar D, Trzaskoma BL, François B, Guy JS, Brückmann M, Rea-Neto A, Rossaint R, Perrotin D, Sablotzki A, Arkins N, Utterback BG, Macias WL; Administration of Drotrecogin Alfa (Activated) in Early Stage Severe Sepsis (ADDRESS) Study Group: Drotrecogin alfa (activated) for adults with severe sepsis and a low risk of death. N Engl J Med 2005, 353:1332-1341.

11. Levi M, Levy M, Williams MD, Douglas I, Artigas A, Antonelli M, Wyncoll D, Janes J, Booth FV, Wang D, Sundin DP, Macias WL; Xigris and Prophylactic HepaRin Evaluation in Severe Sepsis (XPRESS) Study Group: Prophylactic heparin in patients with severe sepsis treated with drotrecogin alfa (activated). Am I Respir Crit Care Med 2007, 176:483-490.

12. Barletta JF, Cooper B, Ohlinger MJ: Adverse drug events associated with disorders of coagulation. Crit Care Med 2010, 38 (6 Suppl):S198-S218.

doi:10.1186/cc10027

Cite this article as: Samama CM, Godier A: Drotrecogin alpha: a rational approach to the treatment of submassive pulmonary embolism? Critical Care 2011, 15:123. 